\title{
PERAN DAYA DUKUNG WILAYAH TERHADAP PENGEMBANGAN USAHA PETERNAKAN SAPI MADURA
}

\author{
Budi Hartono \\ Fakultas Peternakan Universitas Brawijaya \\ Jalan Veteran, Malang, Jawa Timur \\ E -mail: budihartono_ub@yahoo.com
}

Diterima 13 Januari 2012 / Disetujui 1 Juni 2012

\begin{abstract}
Research conducted on the island of Madura. The aim of the research was analyzed the area-based development of beef cattle in Madura island. Primary research data was sourced from statistics in the Madura district in figures. Data was analyzed using Location Quotient $(L Q)$ method. Data procesing conducted whith spreadsheet from Excel on Microsoft Windows 7. The results showed that the basis for the development of Madura cattle each regency were Pamekasan (sub-district Larangan, Pasean, Batumamar, Palengan, Proppo, Tlanakan, and Pegantenan), Sumenep (sub-district Gayam, Nonggunong and Batuputih), Bangkalan (subdistrict Kokop, Geger, Galis, Tanah Merah, and Blega) and Bangkalan (sub-district Ketapang, Sokobanah, Kedungdung, Sampang, Banyuates, Robatal, and Omben. Conclusion of the research was the development of Madura cattle concentrated in the base region of Madura cattle.
\end{abstract}

Keywords: madura cattle, location quotient, base region, carryng capacity

\begin{abstract}
Abstrak: Penelitian dilakukan di wilayah Pulau Madura. Tujuan penelitian adalah menganalisis basis pengembangan Sapi Madura di pulau Madura. Sumber Data utama penelitian adalah statitstik di kabupaten dalam wilayah pulau Madura. Data dianalisis dengan menggunakan Location Quotient (LQ). Data diproses dengan menggunakan program Excel pada Microsoft Windows 7. Hasil penelitian menunjukkan bahwa basis pengembangan Sapi Madura adalah kabupaten Pamekasan (kecamatan Larangan, Pasean, Batumamar, Palengan, Proppo, Tlanakan, dan Pegantenan), kabupaten Sumenep (Kecamatan Gayam, Nonggunong dan Batuputih), kabupaten Bangkalan (kecamatan Kokop, Geger, Galis, Tanah Merah, dan Blega) dan kabupaten Bangkalan (kecamatan Ketapang, Sokobanah, Kedungdung, Sampang, Banyuates, Robatal, dan Omben). Conclusion of the research was the development of Madura cattle concentrated in the base region of Madura cattle.
\end{abstract}

Kata kunci: sapi madura, location quotient, basis pengembangan, daya tampung

\section{PENDAHULUAN}

Kebutuhan daging sapi potong di Indonesia belum terpenuhi sehingga kekurangan tersebut dipenuhi dari impor. Kondisi yang demikian mengisyaratkan peluang untuk pengembangan usaha budidaya ternak sapi potong. Dalam upaya menghadapi kebutuhan daging lokal yang terus meningkat, juga dituntut untuk senantiasa mampu menjaga kontinuitas pasokan ternak ke konsumen (Winarso, 2005). Sumber utama penghasil daging adalah pembibitan sapi potong yang setiap tahunnya diharapkan melahirkan pedet. Usaha pembibitan sapi potong di dalam negeri masih berupa peternakan rakyat, sedang perusahaan swasta yang bergerak di bidang pembibitan sapi potong hingga saat ini belum ada (Prayoga, 2002).

Usaha pembibitan peternakan rakyat berkaitan dengan kebutuhan pakan ternak. Usaha pembibitan relatif tidak memerlukan banyak pakan karena tujuan utamanya adalah untuk menghasilkan pedet, sedangkan penggemukan memerlukan lebih banyak pakan karena tujuan 
utamanya untuk menghasilkan daging dalam waktu singkat (Prayoga, 2002). Diharapkan dengan menerapkan pengembangan kawasan peternakan berbasis peternakan rakyat dapat meningkatkan pendapatan peternak sehingga dapat memberi kontribusi terhadap pendapatan asli daerah (PAD), menyerap tenaga kerja dan memeratakan pendapatan, dan mengaplikasikan teknologi untuk meningkatkan produktivitas (Suyitman, $d k k$. 2009)

Karakteristik geografis pulau Madura yang sebagian besar berbukit, berbatu, dan berupa lahan kering merupakan salah satu faktor penentu bahwa Sapi Madura komoditi dominan di dalam sistem usahatani di wilayah pulau Madura. Irawan dan Pranaji (2002) mengemukakan bahwa fakta empirik mengungkapkan bahwa lahan kering memiliki kuantitas yang sangat besar untuk didayagunakan sebagai faktor produksi pertanian. Rumahtangga petani yang terlibat dalam usaha pertanian lahan kering relatif jauh lebih banyak dan cenderung meningkat. Keadaan ini menjelaskan bahwa ketergantungan rumah tangga petani terhadap lahan kering sebagai sumber pendapatan dan lapangan usaha di perdesaan semakin tinggi.

Potensi sapi potong lokal sebagai penghasil daging belum dimanfaatkan secara optimal melalui perbaikan manajemen pemeliharaan. Sapi lokal memiliki beberapa kelebihan, yaitu daya adaptasinya tinggi terhadap lingkungan setempat, mampu memanfaatkan pakan berkualitas rendah, dan mempunyai daya reproduksi yang baik (Suryana, 2009). Demikian juga halnya dengan Sapi Madura, pakan Sapi Madura pada musim penghujan biasanya rumput gajah, rumput lapang, daun-daunan, dan sebagainya. Pada musim kemarau pakan yang diberikan adalah seadanya meliputi limbah pertanian kering, daun kering, dan sebagainya. Sistem pemeliharaan di tingkat peternak hanya mengandalkan sumber pakan seadanya yang tersedia di daerah setempat. Kualitas pakan yang kurang bagus dan jumlah yang kurang dapat mengganggu proses reproduksi pada ternak. Sapi Madura mempunyai keunggulan yaitu kinerja reproduksi yang lebih baik dibanding dengan Sapi Bos Taurus, lebih tahan terhadap panas dan penyakit caplak (Tety, $d k k$. 2009).
Sapi Madura di samping dimanfaatkan sebagai tenaga kerja, kebutuhan ekonomi yang mampu mendukung perbaikan mutu genetik ternak adalah aspek budaya pemeliharaan secara khusus pada sapi yang terpilih untuk diperlombakan, pajangan dan memberikan kebanggaan tersendiri serta memiliki nilai ekonomis tinggi (harga jual tinggi). Sapi betina dipelihara secara baik yang disiapkan untuk dilombakan sebagai sapi pajangan yang dikenal sebagai Sapi Sonok, sedangkan sapi jantan digunakan untuk pacuan sebagai Sapi Karapan.

Sapi Madura sebagai plasma nutfah sapi potong indigenous merupakan salah satu kebanggaan secara nasional yang perlu dipertahankan keberadaannya. Layaknya Sapi Bali, Sapi Madura juga merupakan sapi potong yang dilindungi keberadaannya di pulau Madura. Mengacu kepada Lembaran Negara (Staadblad) No.226 tahun 1923, No.1465 tahun 1925, No. 368 tahun 1927, No.57 tahun 1934 dan No.115 tahun 1937; serta tersirat didalam UU Nomor 6 tahun 1967 tentang pokok-pokok Peternakan dan Kesehatan Hewan. Peraturan-peraturan tersebut menyebutkan antara lain ditetapkan bahwa pulau Madura dan Bali sebagai tempat pengembangan murni (pure breed) masing-masing untuk Sapi Madura dan Sapi Bali; pelarangan keluar dan masuknya jenis sapi lain dari pulau, pengeluaran dapat dilakukan dengan syarat khususnya diberikan bagi sapi yang tidak produktif atau bukan sebagai bibit (Wijono dan Setiadi, 2007). Kebijakan untuk kepentingan yang khusus maka pengecualian hanya dapat diberikan oleh Menteri Pertanian dengan pengawasan yang ketat dan terjamin tidak akan terjadi pencemaran kemurnian sapi di lingkungannya. Dukungan kebijakan yang konsisten, peninjauan, dan penegasan kembali peraturan pemerintah yang ada, guna tindak lanjut dalam pelaksanaan perlindungan, pemanfaatan dan pengembangan Sapi Madura yang lebih nyata. Seyogyanya pemanfaatan Sapi Madura murni di pulau Madura sebagai populasi dasar yang memungkinkan dikembangkan sebagai bahan dasar untuk membentuk bangsa baru yang unggul dan adaptif untuk daerah tropis, untuk itu program pembibitan ke arah pembentukan bangsa baru dilaksanakan di luar Pulau 
Madura (Wijono dan Setiadi. 2007)

Populasi ternak Sapi Madura meningkat, namun laju peningkatan populasi Sapi Madura lebih rendah dibanding Jawa Timur. Informasi ini dapat digunakan sebagai petunjuk bahwa ada indikasi penurunan keragaan produksi Sapi Madura. Berdasarkan data pemotongan ternak dan produksi daging sapi, ada indikasi bahwa bobot potong Sapi Madura mengalami penurunan sekitar 7,1 persen selama kurun waktu 2006-2008 (Kusmartono, dkk, 2010).

Perkembangan ekonomi tampaknya mempengaruhi pola peternak di pulau Madura. Dinas Peternakan setempat menggalakkan inseminasi buatan atau perkawinan silang antara Sapi Madura dengan Sapi Limousin. Perkawinan silang itu menghasilkan produksi sapi dengan kualitas lebih bagus dari sapi lokal yang dikenal dengan Sapi Limura. Bobot sapi hasil kawin silang ini lebih besar. Penampilan eksterior tubuh dan memiliki pertumbuhan lebih baik dibanding Sapi Madura. Program kawin silang berdampak pada sebagian peternak beralih mengawinkan Sapi Madura dengan Sapi Limosin, sehingga dikhawatirkan akan terjadi penurunan plasma nutfah Sapi Madura. Oleh karena itu perlu dilakukan penelitian yang bertujuan untuk menentukan kawasan basis dan non basis pengembangan Sapi Madura.

\section{METODE PENELITIAN}

Penelitian dilaksanakan di pulau Madura yang meliputi 4 kabupaten yaitu kabupaten Bangkalan, Sampang, Pamekasan, dan Sumenep. Variabel yang diamati yaitu populasi ternak, dan areal tanaman pangan dan perkebunan yang limbahnya dapat dimanfaatkan sebagai sumber pakan ternak. Metode pengumpulan data menggunakan metode studi dokumentasi yaitu mempelajari dokumen-dokumen dan laporanlaporan di berbagai instansi pemerintah. Sumberdata utama adalah data sekunder dari Bangkalan dalam angka 2010, Sampang dalam angka 2010, Pamekasan dalam angka 2010 dan Sumenep dalam angka tahun 2010. Pengolahan dan analisis data dilakukan menggunakan spreadsheet dari Excel dalam Microsoft Windows 7.

Data dianalisis dengan metode LQ (Loca- tion Quotient) (Hendayana, 2003) yaitu sebagai salah satu pendekatan analisis ekonomi basis yang mengidentifikasi komoditas unggulan. Antara (2005) menjelaskan bahwa tujuan penggunaan metode LQ adalah untuk mengidentifikasi atau menentukan sektor basis atau sektor unggulan dalam perekonomian. Rumus LQ dapat dituliskan:

$$
L Q=\frac{p_{i} / p_{t}}{P_{i} / P_{t}}
$$

Keterangan:

LQ adalah Location Quotient, pi adalah komoditas ke-i di kabupaten, pt adalah komoditas total di kabupaten, Pi adalah komoditas ke-i di pulau Madura, dan Pt adalah komoditas total di pulau Madura

\section{Interpretasi Nilai LQ}

(1) Jika LQ > 1, menunjukkan bahwa komoditas ke-i di kabupaten tergolong basis atau lebih spesialis dari komoditas yang sama di pulau Madura. Komoditas memiliki keunggulan komparatif sehingga hasilnya dapat memenuhi di luar wilayah. (2) Jika $\mathbf{L Q}<\mathbf{1}$, menunjukkan bahwa komoditas ke-i di kabupaten tergolong non basis atau kurang spesialis dari komoditas yang sama di pulau Madura. Produksi komoditas ke-i tidak dapat memenuhi kebutuhannya sendiri dan tidak mampu untuk dikirim ke luar wilayah. (3) Jika $\mathbf{L Q}=\mathbf{1}$, menunjukkan bahwa komoditas ke-i di kabupaten tergolong non basis atau tidak memiliki keunggulan komparatif sehingga produksinya hanya mampu memenuhi kebutuhan sendiri dan tidak mampu dikirim ke luar wilayah.

\section{HASIL DAN PEMBAHASAN}

\section{Deskripsi Peternakan Sapi Madura di Madura}

(1) Tingkat Pendidikan. Tingkat pendidikan merupakan salah satu faktor yang mempengaruhi tingkat pendapatan petani, selain luas lahan dan inovasi penelitian. Tingkat pendidikan yang lebih tinggi diharapkan mampu meng- 
Tabel 1. Tingkat Pendidikan Peternak Sapi Madura di 4 Kabupaten di Madura

\begin{tabular}{lcccccc}
\hline \multirow{2}{*}{ Kabupaten } & \multicolumn{2}{c}{ SD } & \multicolumn{2}{c}{ SMP } & \multicolumn{2}{c}{ SMA } \\
\cline { 2 - 7 } & $\mathbf{N}$ & $\mathbf{0}$ & $\mathbf{N}$ & $\mathbf{0}$ & $\mathbf{N}$ & $\mathbf{0}$ \\
\hline Bangkalan & 39 & 78,00 & 6 & 12,00 & 5 & 10,00 \\
Sampang & 34 & 68,00 & 9 & 18,00 & 7 & 14,00 \\
Pamekasan & 38 & 76,00 & 7 & 14,00 & 5 & 10,00 \\
Sumenep & 31 & 62,00 & 11 & 22,00 & 8 & 16,00 \\
\hline
\end{tabular}

Keterangan: $\mathrm{N}=$ Jumlah sampel

adopsi teknologi baru untuk peningkatan pendapatan. Lahan sebagai salah satu faktor industri merupakan tempat di mana produksi barang maupun jasa yang diproduksi, bagi pertanian ketersediaan lahan akan sangat berpengaruh terhadap jumlah produksinya.

Pendidikan dinilai sebagai sarana belajar yang mampu menanamkan pengetahuan, sikap dan keterampilan peternak. Tingkat pendidikan peternak merupakan faktor yang penting karena usaha peternakan sapi potong membutuhkan kecakapan, pengalaman, dan wawasan manajemen usaha. Masyarakat peternak Sapi Madura di Madura pada umumnya berpendidikan Sekolah Dasar (SD) yaitu berkisar antara 62,00-78,00 persen, sedangkan yang berpendidikan Sekolah Menegah Atas (SMA) hanya sebesar 10,00-16,00 persen (Tabel 1). Tingkat pendidikan peternak sapi potong dilokasi penelitian mayoritas hanya sampai tingkat SD. Hal ini tidak jauh berbeda dengan hasil penelitian Deptan (2006) yang menyatakan bahwa tingkat pendidikan tenaga kerja di sektor pertanian pada umumnya rendah sehingga produktivitasnya rendah juga. Pada hal tingkat pendidikan peternak mempengaruhi cara berfikir dan tingkat penerimaan terhadap inovasi dan teknologi. Semakin tinggi tingkat pendidikan peternak, maka akan semakin baik kualitas sumberdaya manusia, yang pada gilirannya akan semakin baik pula produktivitas kerjanya. Dengan demikian semakin tinggi tingkat pendidikan peternak, maka kinerja usaha peternakannya akan semakin baik.

(2) Pengalaman Beternak. Pengalaman usaha menunjukkan lama peternak menjalankan usaha peternakan sapi potong. Pengalaman merupakan suatu pengetahuan peternak yang diperoleh melalui rutinitas kegiatan sehari-hari atau peristiwa yang dialami. Apabila peternak me- miliki pengalaman yang relatif lama dalam mengelola usahanya, umumnya akan memiliki pengetahuan, sikap dan keterampilan yang lebih baik jika dibandingkan dengan peternak yang kurang pengalaman. Pengalaman berusaha membantu peternak dalam mengambil keputusan usaha dan mendukung keberhasilan usahanya. Peternak yang berpengalaman dalam menghadapi permasalahan usahanya akan tahu cara mengatasinya, sedangkan yang kurang pengalaman akan mengalami kesulitan dalam mengatasi permasalahan usahanya.

Keberhasilan usaha peternakan sangat ditentukan oleh pengalaman beternak. Lamanya pengalaman beternak berkorelasi sangat positip dengan keberhasilan usaha peternakan. Berdasarkan hasil pengamatan di lapang, diidentifikasi bahwa sebagian besar peternak sapi Madura di Madura mempunyai pengalaman beternak lebih dari 20 tahun (Tabel 2). Pengalaman yang telah lama didapat ini berpengaruh pada kemampuan peternak Sapi Madura dalam mengelola usaha peternakannya yang pada umumnya berskala kecil yaitu 1-3 ekor per peternak. Tingginya pengalaman beternak juga berpengaruh pada perilaku masyarakat Madura yang selalu mempunyai keinginan yang sangat besar untuk mengadopsi inovasi baru untuk peningkatan produktivitas ternaknya. Tabel 2 menampilkan lamanya pengalaman beternak Sapi Madura di 4 kabupaten di Madura.

(3) Pekerjaan. Pulau Madura merupakan salah satu wilayah yang potensial dalam pengembangan ternak sapi potong, memiliki kondisi lahan yang sesuai serta sumber daya yang mendukung, budidaya sapi potong di pulau Madura lebih berpola pengembangan ternak sapi 
Tabel 2. Pengalaman Beternak Sapi Madura di 4 Kabupaten di Madura

\begin{tabular}{ccccccccc}
\hline \multirow{2}{*}{ Tahun } & \multicolumn{2}{c}{ Bangkalan } & \multicolumn{2}{c}{ Sampang } & \multicolumn{2}{c}{ Pamekasan } & \multicolumn{2}{c}{ Sumenep } \\
\cline { 2 - 10 } & $\mathbf{N}$ & $\mathbf{0}$ & $\mathbf{N}$ & $\mathbf{0}$ & $\mathbf{N}$ & $\mathbf{0}$ & $\mathbf{N}$ & $\mathbf{0}$ \\
\hline$<10$ & 2 & 4,00 & 0 & 0 & 4 & 8,00 & 2 & 4,00 \\
$10-20$ & 3 & 6,00 & 5 & 10,00 & 15 & 30,00 & 5 & 10,00 \\
$>20$ & 45 & 90,00 & 45 & 90,00 & 31 & 62,00 & 43 & 86,00 \\
\hline
\end{tabular}

Keterangan : $\mathrm{N}=$ Jumlah sampel

potong secara pembibitan ketimbang pola penggemukan.

Masyarakat Madura secara umum dalam memenuhi kebutuhan keluarga peternak tidak hanya tergantung pada satu jenis usaha saja melainkan melibatkan beberapa usaha antara lain usaha pertanian, nelayan, non usahatani dan usaha peternakan dalam arti luas itu sendiri. Usaha peternakan secara umum adalah sebagai usaha sampingan yang dimanfaatkan sebagai sumber nafkah ekonomi tambahan. Tabel 3 menunjukkan persentase pekerjaan responden mayoritas petani sebanyak 42,00-70,00 persen. Pada Tabel 3 menunjukkan bahwa usaha peternakan sapi potong sebagai usaha sampingan dalam usaha menambah ekonomi rumahtangga peternak. Kebanyakan penelitian tentang peternakan rakyat sapi potong mempunyai ciri-ciri memiliki lahan terbatas, tingkat pendidikan formal yang rendah dan usaha sapi potong bukan merupakan usaha pokok tetapi merupakan usaha sampingan.

Pola pengembangan sapi potong yang tidak dapat dilepaskan dari perkembangan usaha pertanian terutama sawah dan ladang, karena ternak sapi potong yang merupakan ternak ruminansia pada umumnya limbah pertanian tanaman sebagai sumber pakan. Artinya di setiap wilayah persawahan atau perladangan yang luas maka di sana ditemukan banyak ternak sapi. Peternak memelihara sapi dengan tujuan sebagai sumber tenaga kerja terutama pengolahan tanah dan penarik barang. Oleh karena itu, pertumbuhan pertanian akan mendongkrak pertumbuhan jumlah sapi. Pada sisi lain, perkembangan usaha pertanian berhubungan erat dengan perkembangan penduduk. Penduduk akan semakin padat di wilayah tanah pertanian yang subur. Keadaan ini menciptakan struktur usaha peternakan berskala kecil.

Ternak sangat bermanfaat bagi peternak dan dapat membantu menambah pendapatan keluarga, ada beberapa alasan mengapa memelihara ternak sapi potong diminati oleh responden antara lain a) sebagai tabungan keluarga yang sewaktu-waktu dapat dijual untuk memenuhi kebutuhan, b) kotoran ternak dapat dimanfaatkan sebagai pupuk pada tanaman pangan maupun pupuk untuk perkebunan dan bisa mengurangi pengeluaran untuk biaya pembelian pupuk, c) bisa memanfaatkan hasil limbah pertanian misalnya jerami padi sehingga bermanfaat bagi ternak, d) tenaga kerja ternak sapi potong dapat dimanfaatkan untuk mengolah lahan pertanian dan bisa menekan pengeluaran biaya tenaga kerja.

(4) Tujuan Pengusahaan Sapi. Kesempatan berusaha di luar sektor pertanian di wilayah Madura sangat sempit, olehnya memelihara ternak sapi potong bagi petani merupakan salah satu bagian untuk mendukung dalam memenuhi kebutuhan keluarga peternak, peternak memanfaatkan tenaga kerja keluarga untuk

Tabel 3. Pekerjaan Responden di 4 Kabupaten di Madura

\begin{tabular}{|c|c|c|c|c|c|c|}
\hline \multirow{3}{*}{ Kabupaten } & \multicolumn{6}{|c|}{ Pekerjaan Utama } \\
\hline & \multicolumn{2}{|c|}{ PNS } & \multicolumn{2}{|c|}{ Petani } & \multicolumn{2}{|c|}{ Wiraswasta } \\
\hline & $\mathbf{N}$ & $\%$ & $\mathbf{N}$ & $\%$ & $\mathbf{N}$ & $\%$ \\
\hline Bangkalan & 0 & 0 & 23 & 46,00 & 27 & 54,00 \\
\hline Sampang & 0 & 0 & 21 & 42,00 & 29 & 58,00 \\
\hline Pamekasan & 7 & 14,00 & 35 & 70,00 & 8 & 16,00 \\
\hline Sumenep & 0 & 0 & 24 & 48,00 & 26 & 52,00 \\
\hline
\end{tabular}


Tabel 4. Distribusi Peternak Berdasarkan Tujuan Pengusahaan Sapi

\begin{tabular}{lrrrrrr}
\hline \multirow{2}{*}{ Kabupaten } & \multicolumn{2}{c}{ Pembibitan } & \multicolumn{2}{c}{ Bakalan } & \multicolumn{2}{c}{ Persilangan } \\
\cline { 2 - 7 } & $\mathbf{N}$ & $\mathbf{0}$ & $\mathbf{N}$ & $\mathbf{0}$ & $\mathbf{N}$ & $\mathbf{0}$ \\
\hline Bangkalan & 22 & 44,00 & 25 & 50,00 & 3 & 6,00 \\
Sampang & 20 & 40,00 & 28 & 56,00 & 2 & 4,00 \\
Pamekasan & 19 & 38,00 & 30 & 60,00 & 1 & 2,00 \\
Sumenep & 6 & 12,00 & 32 & 64,00 & 12 & 24,00 \\
\hline
\end{tabular}

merumput atau mengumpulkan sisa-sisa hasil pertanian yang tidak dimanfaatkan untuk peternak dimanfaatkan untuk pakan ternak, dan selanjutnya ternak mendatangkan keuntungan yang berupa anak sapi, nilai ternak, dan kotoran ternak sebagai pupuk. Walaupun tujuan peternak memelihara sapi potong adalah mendapatkan keuntungan namun di sisi lain ternak sapi potong memiliki nilai status sosial di masyarakat.

Tujuan penyelenggaraan usaha peternakan sapi bakalan menduduki ranking tertinggi di setiap kabupaten (50,00-64,00 persen), usaha pembibitan di tempat ke dua dan persilangan di tempat terakhir. Pola pembibitan ternak dilakukan oleh peternak pada mulanya dilakukan untuk usaha tabungan namum lama-kelamaan untuk usaha komersial. Teknik pembibitan dilakukan dengan sistem kawin suntik (Inseminasi Buatan-IB) dan ada juga yang dilakukan dengan sistem kawin alam (KA). Keberhasilan kebuntingan sapi induk biasanya dicapai dengan frekuensi penyuntikan sebanyak 2-3 kali, bahkan bisa mencapai 4 kali Jasa pelayanan kawin suntik setiap kali inseminasi petugas yang ada di lapangan, sedangkan kawin alam dilakukan dengan cara meminjam pejantan kepada peternak di sekitar yang memiliki ternak sapi pejantan dengan biaya bervariasi tergantung kualitas pejantannya.

\section{Analisis LQ}

Di pulau Madura jenis ternak ruminansia yang sudah tidak asing lagi adalah ternak Sapi Madura. Ternak sapi penyebarannya relatif luas merata hampir semua desa dan kecamatan. Keragaan penyebaran komoditas ternak sapi potong berdasarkan nilai LQ yang dapat dibedakan menjadi dua kriteria yaitu LQ $>1$ yang berarti ternak sapi potong merupakan basis daerah tertentu dan LQ $<1$ yang berarti non basis. Untuk jelasnya perhatikan Tabel 5 dalam Lampiran, Tabel 6 dalam Lampiran, Tabel 7 Lampiran, dan Tabel 8 dalam Lampiran.

Kisaran nilai LQ, wilayah kabupaten Pamekasan dalam usaha ternak sapi potong mempunyai nilai LQ berkisar antara 0,31 sampai 2,62 . Dengan nilai 2,62 berarti populasi sapi potong itu terkonsentrasi yang jumlahnya 2,62 lebih tinggi dibandingkan populasi di kabupaten Pamekasan. Wilayah kabupaten Pemekasan terdapat 7 wilayah kecamatan yang merupakan basis pengembangan ternak sapi potong. Secara berurutan kecamatan yang mempunyai nilai LQ $>1$ mulai yang paling besar sampai yang kecil adalah kecamatan Larangan, Pasean, Batumamar, Palengan, Proppo, Tlanakan, dan Pegantenan masing-masing adalah 2,62; 2,19; 1,36; 1,25; 1,23; 1,00; dan 1,00 (Tabel 5 dalam Lampiran). Dengan demikian ke 7 kecamatan tersebut mampu memproduksi sapi potong untuk kepentingan wilayah sendiri maupun mampu membantu wilayah lain yang kekurangan ternak sapi potong.

Dalam wilayah kabupaten Sumenep hanya terdapat 3 kecamatan yang merupakan basis pengembangan sapi potong di antara 27 kecamatan lainnya. Kecamatan yang mempunyai nilai LQ $>1$ secara berurutan yaitu kecamatan Gayam, Nonggunong, dan Batuputih dengan nilai masing-masing adalah 1,$61 ; 1,27$ dan 1,02 (Tabel 6 dalam Lampiran). Dengan demikian tiga kecamatan tersebut mampu memproduksi sapi potong untuk kepentingan wilayah sendiri maupun mampu membantu wilayah lain yang kekurangan ternak sapi potong.

Wilayah di kabupaten Bangkalan ada 6 kecamatan yang mempunyai keunggulan dalam usaha pengembangan ternak sapi potong. Kecamatan yang paling unggul (basis) pengembangan ternak sapi potong di kabupaten Bang- 
kalan adalah kecamatan Kokop dengan nilai LQ sebesar 2,31. Urutan berikutnya adalah kecamatan Geger, Galis, Tanah Merah, Sepulu, dan Blega dengan nilai LQ masing-masing adalah 1,$77 ; 1,52 ; 1,25,1,22$; dan 1,09. Kecamatan selain tersebut di atas yaitu sebanyak 12 kecamatan dapat dikatakan sebagai non basis pengembangan ternak sapi potong dengan nilai $L Q<1$ (Tabel 7 dalam Lampiran).

Wilayah kabupaten Sampang terdapat 7 kecamatan yang dapat dikatakan sebagai basis pengembangan sapi potong dengan nilai LQ paling besar 2,33 yang diduduki oleh kecamatan Ketapang. Kecamatan lain yang merupakan basis pengembangan sapi potong adalah kecamatan Sokobanah, Kedungdung, Sampang, Banyuates, Robatal, dan Omben dengan range nilai LQ antara 1,68 sampai 1,23 (Tabel 8 dalam Lampiran).

\section{Analisis Daya Dukung Limbah Pertanian}

Pengembangan sapi potong di pulau Madura yang tidak dapat dipisahkan dari perkembangan usaha pertanian, terutama sawah dan ladang. Secara geografis wilayah Pulau Madura merupakan wilayah dataran dan pegunungan yang memiliki potensi lahan pertanian besar. Lahan yang beririgasi teknis sampai lahan kering merupakan potensi untuk mendukung pengembangan sapi potong. Penggunaan lahan yang demikian memperlihatkan ketersediaan bahwa wilayah ini memiliki potensi ketersediaan limbah pertanian sangat besar yang dapat dimanfaatkan untuk pengembangan ternak. Oleh karena itu tidaklah mengherankan apabila wilayah Madura merupakan lumbung ternak nasional khusus breed Sapi Madura. Hal inilah yang menjadikan usaha pengembangan ternak sapi potong dapat berkembang. Dengan demikian akan dapat memberikan peluang usaha dan dapat memberikan tambahan pendapatan sebagian masyarakat di perdesaan yang mengusahakannya.

Lahan beririgasi secara teknis biasanya ditanami padi yang dalam satu tahun dapat ditanami sebanyak 3 kali namun untuk daerah tertentu hanya ditanami sebanyak 2 kali. Limbah padi yang sering dikenal sebagai jerami merupakan bahan pakan ternak yang potensial.
Jerami dapat diberikan ke ternak sapi dapat dalam bentuk segar ataupun dikeringkan. Dalam analisis potensi limbah pertanian sebagai pendukung pengembangan ternak sapi potong di Pulau Madura hanya dibatasi 7 komoditi saja seperti limbah padi, jagung, ubi kayu, kacang tanah, kedelai, ubi jalar, dan kacang hijau karena keterbatasan data.

Jumlah produksi limbah segar pertanian di kabupaten Pamekasan adalah paling banyak di kecamatan Batumamar yang mampu menopang sapi potong sebanyak 13.533 ekor (Tabel 5 dalam Lampiran). Padahal populasinya hanya 9.9934 ekor, sehingga kecamatan Batumamar dapat membantu wilayah sekitarnya yang kekurangan bahan pakan dari limbah pertanian. Wilayah kecamatan lainnya seperti Larangan, Pasean, Palengan, Proppo, Tlanakan, dan Pegantenan limbah tanaman pangan mampu menyuplai pakan bervariasi mulai 19,82 persen sampai 91,54 persen. Kekurangannya dapat diambilkan dari potensi lahan perkebunan, padang rumput, lahan hutan, dan tanaman pangan lainnya.

Pemberian limbah pertanian sebagai pakan sapi potong di kabupaten Pamekasan hanya dengan mencincang yang selanjutnya diberikan kepada ternak baik dalam bentuk segar maupun kering. Pemberian dalam bentuk segar diberikan pada saat musim panen dan dalam bentuk kering biasanya diberikan pada saat musim kemarau atau pada saat rumput alam sulit didapatkan. Pemberian limbah pertanian pada sapi potong tidak dapat diberikan secara tunggal (single ingredient), akan tetapi perlu campuran dengan campuran dari limbah pertanian lainnya.

Pemberian jerami jagung dan jerami kacang kedele umumnya diberikan kepada ternak sapi potong dalam bentuk segar, dan jarang diberikan dalam bentuk kering. Hal ini disebabkan karena jerami jagung cepat rusak (menjamur) apabila disimpan dalam waktu yang lama tanpa pengeringan yang tepat.

Potensi limbah tanaman pangan juga dimanfaatkan di kabupaten Sumenep. Kecamatan yang merupakan basis pengembangan ternak sapi potong (kecamatan Gayam, Nonggunong, dan Batuputih) justru limbah pertanian sebagai 
pakan hanya mampu menyuplai 28,9 persen sampai 66,54 persen karena lahan yang ditanami tanaman pangan tidak begitu luas sehingga hasil limbah juga tidak begitu banyak (Tabel 6 dalam Lampiran). Di wilayah kabupaten Bangkalan (Tabel 7 dalam Lampiran) hanya kecamatan Blega yang merupakan basis pengembangan sapi potong yang mampu disuplai dari limbah tanaman pangan karena produksi limbah sangat banyak. Sedang di kecamatan lain seperti Kwanyar, Modung, Konang, Tragah, Socah, Burneh, dan Klampis sangat surplus limbah tanaman pangan sebagai sumber pakan ternak sapi potong, sehingga masih memungkinkan untuk dikembangkan lebih lanjut.

Wilayah kabupaten Sampang terdapat 3 kecamatan yang basis pengembangan sapi potong mampu disuplai dari limbah pertanian yaitu kecamatan Omben, Banyuates, dan Sokobanah yang masing-masing mempunyai kelebihan sebanyak 9,3 persen; 39,8 persen; dan 57,0 persen (Tabel 8 dalam Lampiran). Sedang kecamatan lain seperti Sreseh, Jengrik, Tambelangan, dan Karangpenang sangat mungkin untuk dikembangkan lebih lanjut usaha ternak sapi potong karena banyak limbah tanaman pangan yang kurang dimanfaatkan.

\section{SIMPULAN}

Dalam menetapkan kebijakan pembangunan peternakan sapi potong di Madura sebagai daerah tertutup dalam rangka mempertahankan kemurnian Sapi Madura sebagai plasma nutfah asli Indonesia sebaiknya pengembangan ternak Sapi Madura dipusatkan di wilayah basis ternak Sapi Madura, sehingga mampu meningkatkan pendapatan peternak.

\section{DAFTAR PUSTAKA}

Antara, M. 2005. Kebutuhan Investasi Sektor Basis dan Non Basis dalam Perekonomian Regional Bali. Pengajar pada Program Magister Agribisnis, Program Pascasarjana. Universitas Udayana.
BPS. 2010a. Kabupaten Pamekasan dalam Angka 2010. Pamekasan: Badan Pusat Statistik.

BPS. 2010b. Kabupaten Sumenep dalam Angka 2010. Sumenep: Badan Pusat Statistik.

BPS. 2010c. Bangkalan dalam Angka 2010. Bangkalan: Badan Pusat Statistik.

BPS. 2010d. Kabupaten Sampang dalam Angka 2010. Sampang: Badan Pusat Statistik.

Deptan. 2006. Rencana Pembangunan Pertanian Tahun 2005-2009. Jakarta: Departemen Pertanian.

Hendayana, R. 2003. Aplikasi Metode Location Quotient (LQ) dalam Penentuan Komoditas Unggulan Nasional. Jurnal Informatika Pertanian. Vol. 12. Edisi Desember 2003. Hal. 1-21.

Irawan, B., dan T. Pranadji. 2002. Pemberdayaan Lahan Kering untuk Pengembangan Agribisnis Berkelanjutan. Forum Penelitian Agro Ekonomi (FAE). Edisi Desember .Vol. 20. No. 2. Hal. 60-76.

Kusmartono, Hartutik, S.B. Siswijono, V.MA. Nurgiartiningsih dan Nuryadi. 2010. Penyusunan Grand Design Pengembangan Peternakan di Madura. Laporan Penelitian. Dinas Peternakan Provinsi Jawa Timur.

Prayoga, U.H. dan N. Ilham. 2002. Problem dan Prospek Pengembangan Usaha Pembibitan Sapi Potong di Indonesia. Jurnal Litbang Pertanian. Vol. 21 No. 4. Hal. 148-157.

Suryana. 2009. Pengembangan Usaha Ternak Sapi Potong Berorientasi Agribisnis dengan Pola Kemitraan. Jurnal Litbang Pertanian, 28(1), hal. 29-37.

Suyitman, Surjono, H.S., C. Herison dan Muladno. 2009. Status Keberlanjutan Wilayah Berbasis Peternakan di kabupaten Situbondo untuk Pengembangan Kawasan Agropolitan. Jurnal Agro Ekonomi. Vol. 27 No. 2. Hal. 165-191.

Tety, H., D.A. Mahardika, T.S.M. Widi dan E. Baliarti. 2009. Karaktersitik dan Kinerja Induk Sapi Silangan Limousin-Madura dan Madura di Kabupaten Sumenep dan 
Pamekasan. Buletin Peternakan Vol. 33 (3): Winarso, B., Rosmiyati S dan C Muslim. 2005. 143-147.

Wijono, D.B dan B. Setiadi. 2007. Potensi dan Keragaman Sumberdaya Genetik. http:// Tinjauan Ekonomi Ternak Sapi Potong di Jawa Timur. Forum Penelitian Agro Ekomaduracenter.wordpress.com/ di akses nomi. Vol. 23. No. 1. Hal. 61-71.

15 Nopember 2011.

\section{LAMPIRAN}

Tabel 5. Nilai LQ dan Daya Dukung Limbah Pertanian Kabupaten Pamekasan

\begin{tabular}{|c|c|c|c|c|c|c|c|c|c|c|}
\hline \multirow{2}{*}{ Kecamatan } & \multirow{2}{*}{ 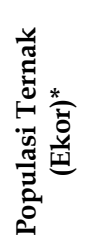 } & \multirow{2}{*}{ 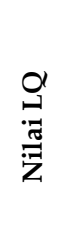 } & \multirow{2}{*}{ 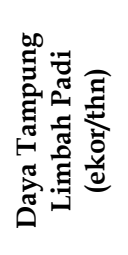 } & \multirow{2}{*}{ 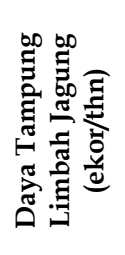 } & \multirow{2}{*}{ 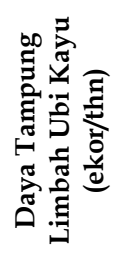 } & \multirow{2}{*}{ 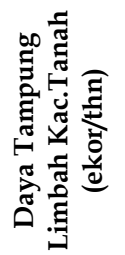 } & \multirow{2}{*}{ 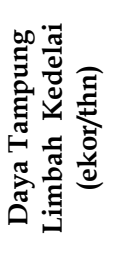 } & \multirow{2}{*}{ 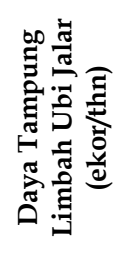 } & \multicolumn{2}{|c|}{$\begin{array}{c}\text { Total } \\
\text { Daya } \\
\text { Tampung }\end{array}$} \\
\hline & & & & & & & & & Ekor & $\%$ \\
\hline Tlanakan & 7352 & 1,00 & 402 & 1018 & 55 & 55 & 0 & 16 & 1546 & 21,03 \\
\hline Pademawu & 7184 & 0,98 & 1590 & 1528 & 58 & 2 & 0 & 0 & 3178 & 44,23 \\
\hline Galis & 5514 & 0,76 & 1945 & 39 & 3 & 4 & 0 & 1 & 1993 & 36,14 \\
\hline Larangan & 19099 & 2,62 & 1821 & 1799 & 66 & 97 & 4 & 0 & 3786 & 19,82 \\
\hline Pamekasan & 2268 & 0,31 & 910 & 1006 & 2 & 25 & 9 & 0 & 1952 & 86,07 \\
\hline Proppo & 8983 & 1,23 & 2880 & 1096 & 79 & 234 & 0 & 0 & 4289 & 47,75 \\
\hline Palengaan & 9129 & 1,25 & 836 & 6496 & 225 & 584 & 182 & 33 & 8357 & 91,54 \\
\hline Pegantenan & 7343 & 1,00 & 1858 & 1778 & 56 & 219 & 36 & 2 & 3949 & 53,78 \\
\hline Kadur & 7284 & 0,99 & 466 & 3866 & 25 & 104 & 0 & 0 & 4461 & 61,25 \\
\hline Pakong & 7284 & 0,99 & 3189 & 1386 & 69 & 381 & 249 & 0 & 5275 & 72,42 \\
\hline Waru & 7072 & 0,96 & 1507 & 3878 & 23 & 32 & 0 & 0 & 5440 & 76,93 \\
\hline Batumamar & 9934 & 1,36 & 1535 & 11573 & 65 & 349 & 7 & 5 & 13533 & 136,2 \\
\hline Pasean & 15965 & 2,19 & 592 & 4199 & 73 & 168 & 0 & 0 & 5032 & 31,52 \\
\hline
\end{tabular}

Keterangan : * BPS. 2010a. Kabupaten Pamekasan dalam Angka 2010.

Tabel 6. Nilai LQ dan Daya Dukung Limbah Pertanian Kabupaten Sumenep

\begin{tabular}{|c|c|c|c|c|c|c|c|c|c|c|}
\hline \multirow{2}{*}{ Kecamatan } & \multirow{2}{*}{ 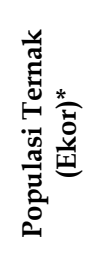 } & \multirow{2}{*}{ 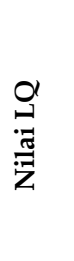 } & \multirow{2}{*}{ 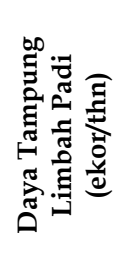 } & \multirow{2}{*}{ 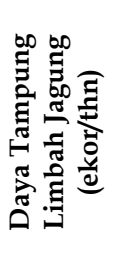 } & \multirow{2}{*}{ 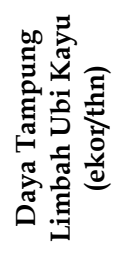 } & \multirow{2}{*}{ 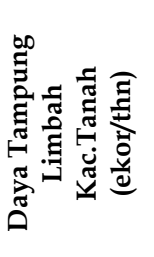 } & \multirow{2}{*}{ 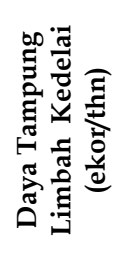 } & \multirow{2}{*}{ 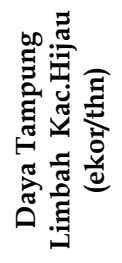 } & \multicolumn{2}{|c|}{$\begin{array}{c}\text { Total } \\
\text { Daya } \\
\text { Tampung }\end{array}$} \\
\hline & & & & & & & & & Ekor & $\%$ \\
\hline Sumenep & 2314 & 0,14 & 946 & 2013 & 12 & 41 & 31 & 14 & 3056 & 132,1 \\
\hline Batuan & 1755 & 0,11 & 907 & 1812 & 29 & 210 & 2 & 98 & 3057 & 174,2 \\
\hline Kalianget & 2068 & 0,13 & 37 & 576 & 59 & 149 & 0 & 260 & 1081 & 52,26 \\
\hline Manding & 12657 & 0,80 & 1428 & 4484 & 47 & 157 & 46 & 65 & 6228 & 49,21 \\
\hline Talango & 11215 & 0,71 & 0 & 2967 & 222 & 75 & 0 & 242 & 3506 & 31,26 \\
\hline Batang-Batang & 8608 & 0,54 & 1030 & 4870 & 139 & 805 & 15 & 653 & 7512 & 87,27 \\
\hline Batuputih & 16172 & 1,02 & 423 & 9539 & 143 & 276 & 19 & 360 & 10761 & 66,54 \\
\hline
\end{tabular}




\begin{tabular}{|c|c|c|c|c|c|c|c|c|c|c|}
\hline \multirow[t]{2}{*}{ Kecamatan } & \multirow{2}{*}{ 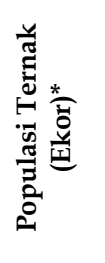 } & \multirow{2}{*}{ 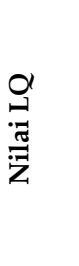 } & \multirow{2}{*}{ 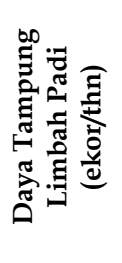 } & \multirow{2}{*}{ 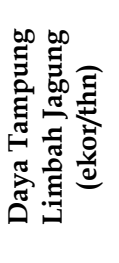 } & \multirow{2}{*}{ 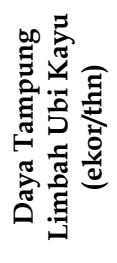 } & \multirow{2}{*}{ 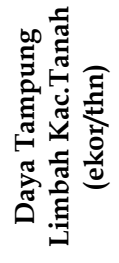 } & \multirow{2}{*}{ 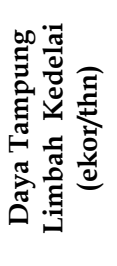 } & \multirow{2}{*}{ 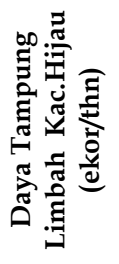 } & \multicolumn{2}{|c|}{$\begin{array}{c}\text { Total } \\
\text { Daya } \\
\text { Tampung }\end{array}$} \\
\hline & & & & & & & & & Ekor & $\%$ \\
\hline Gapuro & 7740 & 0,49 & 978 & 4222 & 143 & 308 & 117 & 431 & 6199 & 80,09 \\
\hline Dungkek & 14677 & 0,93 & 512 & 6064 & 204 & 308 & 14 & 19 & 7121 & 48,52 \\
\hline Ambunten & 13740 & 0,87 & 522 & 5524 & 66 & 344 & 37 & 817 & 7310 & 53,20 \\
\hline Pasongsongan & 11894 & 0,75 & 1465 & 7140 & 69 & 438 & 35 & 2028 & 11175 & 93,95 \\
\hline Rubaru & 13921 & 0,88 & 1062 & 8167 & 132 & 239 & 23 & 102 & 9725 & 69,86 \\
\hline Dasuk & 6112 & 0,39 & 680 & 4865 & 20 & 136 & 8 & 96 & 5804 & 94,97 \\
\hline Guluk-guluk & 8012 & 0,51 & 1481 & 7249 & 91 & 287 & 694 & 709 & 10511 & 131,20 \\
\hline Ganding & 9864 & 0,62 & 1108 & 6121 & 108 & 385 & 792 & 86 & 8599 & 87,18 \\
\hline Pragaan & 4678 & 0,30 & 187 & 5815 & 28 & 47 & 23 & 1960 & 8060 & 172,30 \\
\hline Bluto & 9297 & 0,59 & 88 & 3222 & 25 & 64 & 55 & 788 & 4243 & 45,64 \\
\hline Saronggi & 11458 & 0,72 & 741 & 4761 & 341 & 63 & 4 & 3663 & 9572 & 83,53 \\
\hline Lenteng & 15162 & 0,96 & 1063 & 9111 & 122 & 313 & 715 & 404 & 11728 & 77,35 \\
\hline Giligenteng & 4886 & 0,31 & 0 & 1043 & 36 & 15 & 0 & 323 & 1417 & 29,00 \\
\hline Gayam & 25522 & 1,61 & 468 & 7487 & 148 & 283 & 0 & 306 & 8692 & 34,06 \\
\hline Nonggunong & 20185 & 1,27 & 447 & 4505 & 234 & 280 & 48 & 318 & 5832 & 28,90 \\
\hline Ra`as & 3406 & 0,21 & 281 & 4125 & 18 & 5 & 9 & 75 & 4513 & 132,50 \\
\hline Arjasa & 6823 & 0,43 & 7241 & 11118 & 2261 & 144 & 32 & 1082 & 21879 & 320,70 \\
\hline Kangayan & 2194 & 0,14 & 836 & 2481 & 165 & 78 & 48 & 82 & 3690 & 168,20 \\
\hline Sapeken & 1142 & 0,07 & 640 & 4462 & 143 & 12 & 86 & 75 & 5419 & 474,50 \\
\hline Masalembu & 2964 & 0,19 & 0 & 4364 & 513 & 30 & 10 & 59 & 4976 & 167,90 \\
\hline
\end{tabular}

Keterangan : * BPS. 2010b. Kabupaten Sumenep dalam Angka 2010.

Tabel 7. Nilai LQ dan Daya Dukung Limbah Pertanian Kabupaten Bangkalan

\begin{tabular}{|c|c|c|c|c|c|c|c|c|c|c|c|}
\hline \multirow[t]{2}{*}{ Kecamatan } & \multirow{2}{*}{ 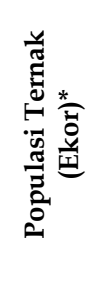 } & \multirow{2}{*}{ 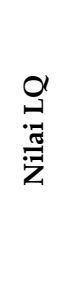 } & \multirow{2}{*}{ 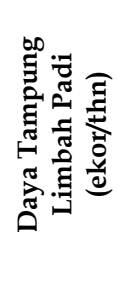 } & \multirow{2}{*}{ 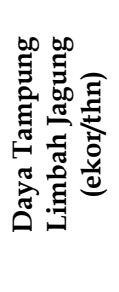 } & \multirow{2}{*}{ 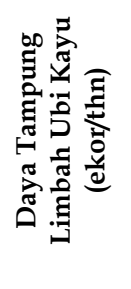 } & \multirow{2}{*}{ 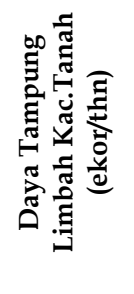 } & \multirow{2}{*}{ 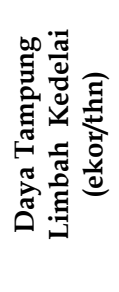 } & \multirow{2}{*}{ 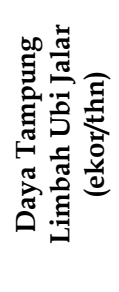 } & \multirow{2}{*}{ 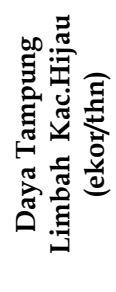 } & \multicolumn{2}{|c|}{$\begin{array}{c}\text { Total } \\
\text { Daya } \\
\text { Tampung }\end{array}$} \\
\hline & & & & & & & & & & Ekor & $\%$ \\
\hline Kamal & 2461 & 0,32 & 1276 & 1618 & 16 & 314 & 0 & 2 & 0 & 3226 & 131,10 \\
\hline Labang & 6380 & 0,82 & 658 & 1380 & 57 & 230 & 0 & 0 & 0 & 2325 & 36,44 \\
\hline Kwanyar & 3690 & 0,47 & 1212 & 3416 & 25 & 1427 & 177 & 7 & 314 & 6577 & 178,20 \\
\hline Modung & 6008 & 0,77 & 2444 & 7934 & 37 & 2287 & 229 & 36 & 203 & 13171 & 219,20 \\
\hline Blega & 8468 & 1,09 & 3022 & 9751 & 25 & 2414 & 487 & 6 & 126 & 15826 & 186,90 \\
\hline Konang & 4048 & 0,52 & 2120 & 3405 & 22 & 4967 & 262 & 17 & 818 & 11611 & 286,80 \\
\hline Galis & 11870 & 1,52 & 976 & 5345 & 153 & 1096 & 183 & 238 & 438 & 8430 & 71,02 \\
\hline Tanah Merah & 9735 & 1,25 & 2059 & 3070 & 32 & 1425 & 87 & 0 & 160 & 6833 & 70,19 \\
\hline Tragah & 4153 & 0,53 & 1341 & 2808 & 51 & 927 & 0 & 9 & 11 & 5146 & 123,90 \\
\hline Socah & 4321 & 0,55 & 2162 & 1645 & 53 & 1504 & 0 & 1 & 0 & 5365 & 124,20 \\
\hline Bangkalan & 3363 & 0,43 & 1423 & 408 & 15 & 166 & 0 & 33 & 0 & 2045 & 60,81 \\
\hline Burneh & 3268 & 0,42 & 4914 & 3029 & 43 & 1261 & 0 & 248 & 0 & 9495 & 290,50 \\
\hline
\end{tabular}




\begin{tabular}{|c|c|c|c|c|c|c|c|c|c|c|c|}
\hline \multirow[t]{2}{*}{ Kecamatan } & \multirow{2}{*}{ 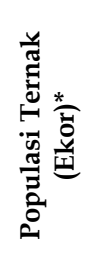 } & \multirow{2}{*}{ 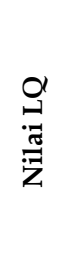 } & \multirow{2}{*}{ 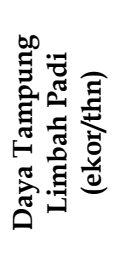 } & \multirow{2}{*}{ 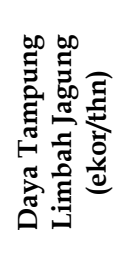 } & \multirow{2}{*}{ 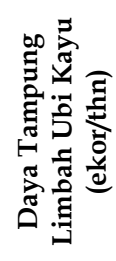 } & \multirow{2}{*}{ 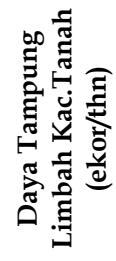 } & \multirow{2}{*}{ 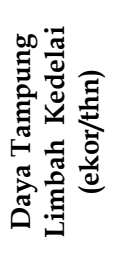 } & \multirow{2}{*}{ 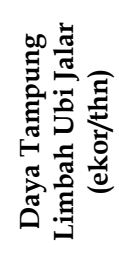 } & \multirow{2}{*}{ 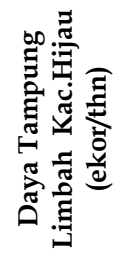 } & \multicolumn{2}{|c|}{$\begin{array}{c}\text { Total } \\
\text { Daya } \\
\text { Tampung }\end{array}$} \\
\hline & & & & & & & & & & Ekor & $\%$ \\
\hline Arosbaya & 5054 & 0,65 & 3210 & 1029 & 11 & 1039 & 20 & 0 & 99 & 5407 & 107,00 \\
\hline Geger & 13834 & 1,77 & 3661 & 4517 & 525 & 6469 & 4 & 40 & 984 & 16199 & 117,10 \\
\hline Kokop & 18042 & 2,31 & 1861 & 4194 & 494 & 392 & 0 & 603 & 380 & 7924 & 43,92 \\
\hline Tanjungbumi & 3783 & 0,49 & 1158 & 3503 & 134 & 298 & 0 & 14 & 226 & 5333 & 141,00 \\
\hline Sepulu & 9512 & 1,22 & 1558 & 2265 & 15 & 699 & 0 & 9 & 609 & 5154 & 54,19 \\
\hline Klampis & 4416 & 0,57 & 1250 & 4451 & 138 & 1621 & 0 & 0 & 466 & 7926 & 179,50 \\
\hline
\end{tabular}

Keterangan: * BPS. 2010c. Bangkalan dalam Angka 2010

Tabel 7. Nilai LQ dan Daya Dukung Limbah Pertanian Kabupaten Sampang

\begin{tabular}{|c|c|c|c|c|c|c|c|c|c|c|c|}
\hline \multirow[t]{2}{*}{ Kecamatan } & \multirow{2}{*}{ 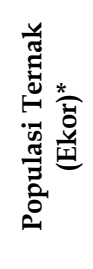 } & \multirow{2}{*}{ 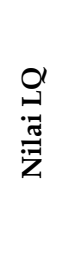 } & \multirow{2}{*}{ 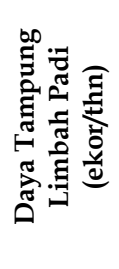 } & \multirow{2}{*}{ 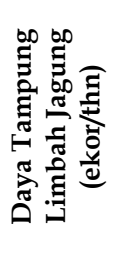 } & \multirow{2}{*}{ 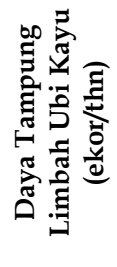 } & \multirow{2}{*}{ 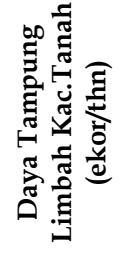 } & \multirow{2}{*}{ 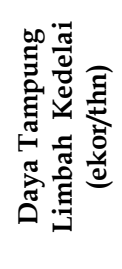 } & \multirow{2}{*}{ 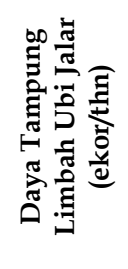 } & \multirow{2}{*}{ 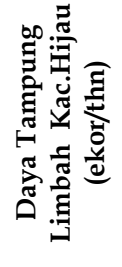 } & \multicolumn{2}{|c|}{$\begin{array}{c}\text { Total } \\
\text { Daya } \\
\text { Tampung }\end{array}$} \\
\hline & & & & & & & & & & Ekor & $\%$ \\
\hline Sreseh & 5013 & 0,56 & 1208 & 3756 & 19 & 2054 & 0 & 46 & 1100 & 8183 & 163,20 \\
\hline Torjun & 5320 & 0,60 & 2336 & 1336 & 5 & 230 & 2 & 0 & 121 & 4027 & 75,70 \\
\hline Pangarengan & 3710 & 0,42 & 722 & 1936 & 5 & 140 & 0 & 0 & 79 & 2881 & 77,66 \\
\hline Sampang & 12983 & 1,45 & 2679 & 2077 & 104 & 175 & 0 & 26 & 137 & 5197 & 40,03 \\
\hline Camplong & 8406 & 0,94 & 1521 & 3469 & 334 & 638 & 0 & 358 & 328 & 6647 & 79,07 \\
\hline Omben & 10994 & 1,23 & 4749 & 4199 & 1231 & 1509 & 19 & 63 & 245 & 12015 & 109,30 \\
\hline Kedungdung & 14452 & 1,62 & 3030 & 3 & 709 & 2335 & 0 & 328 & 419 & 6823 & 47,21 \\
\hline Jrengik & 6648 & 0,74 & 3293 & 2305 & 13 & 844 & 18 & 0 & 714 & 7186 & 108,10 \\
\hline Tambelangan & 5348 & 0,60 & 2258 & 3156 & 460 & 1623 & 0 & 160 & 489 & 8147 & 152,30 \\
\hline Banyuates & 12502 & 1,40 & 1689 & 6939 & 538 & 5055 & 8 & 9 & 3240 & 17477 & 139,80 \\
\hline Robatal & 11104 & 1,24 & 1837 & 157 & 597 & 261 & 1438 & 123 & 87 & 5914 & 53,26 \\
\hline Karang Penang & 7710 & 0,86 & 697 & 5407 & 526 & 242 & 3901 & 132 & 40 & 10945 & 142,00 \\
\hline Ketapang & 20865 & 2,33 & 666 & 10204 & 798 & 3289 & 59 & 0 & 2040 & 17055 & 81,74 \\
\hline Sokobanah & 14989 & 1,68 & 454 & 17946 & 371 & 2141 & 2494 & 0 & 130 & 23537 & 157,00 \\
\hline
\end{tabular}

Keterangan : * BPS. 2010d. Kabupaten Sampang dalam Angka 2010 